\title{
脳卒中リハビリテーション患者における血清アルブミン值と 患者転帰の関係
}

\author{
小野恭裕*1 本田透*1 桑嶋 博史*1 \\ 菰㴊真紀*1 山田耕平*1 横山茂樹*2
}

\section{Relationship between Serum Albumin Level and Long-term Prognosis in Patients with Cerebral Apoplexy}

\author{
Yasuhiro Ono, ${ }^{* 1}$ Toru Honda, ${ }^{* 1}$ Hiroshi Kuwajima, ${ }^{* 1}$ \\ Maki KomoBuchi, ${ }^{* 1}$ Kouhei Yamada, ${ }^{* 1}$ Shigeki YoKoYamA ${ }^{* 2}$
}

\begin{abstract}
Objective : Serum albumin is important marker in all aspects of stroke care including rehabilitation. We examined the serum albumin level of stroke patients, and investigated the relation between their serum albumin level and their prognosis. Methods : The serum albumin levels of 295 patients enrolled from 2008 to 2014 were sequentially checked in our hospital and in subsequent rehabilitation hospitals. Functional outcome was measured by functional independence measure (FIM) at the time of discharge from the rehabilitation hospital. Results : In all types (cerebral infarction, cerebral hemorrhage and subarachnoid hemorrhage (SAH)) of apoplexy, serum albumin levels were the highest at the time of admission, temporarily declined after admission, and almost recovered at the time of discharge. In SAH, the serum albumin levels deteriorated at a greater rate than in other types of stroke. In cerebral infarction and cerebral hemorrhage, the lowest serum albumin level was positively correlated with FIM at the time of discharge from the rehabilitation hospital $(p<0.001)$. But, in SAH, there was no significant correlation between the lowest serum albumin level and FIM at the time of discharge $(p=0.844)$. Conclusion : Our data suggest that serum albumin level is associated with the outcome of stroke patients, except for SAH patients. Serum albumin level should be one of the prognostic factors used in stroke patients, but we should consider that SAH patients are exceptional because of other neurological complications. (Jpn J Rehabil Med 2015; $52: 550-554$ )
\end{abstract}

\footnotetext{
要 旨 目的：当院で急性期リハビリテーション（以下，リハ）を行った脳卒中患者の血清 アルブミン值の継時的変化を病型別に解析し，転帰との関係を検討した。方法：2008 年から 2014 年の急性期リハを行い, リハ連携病院での転帰情報が得られた 295 名を対象とした。血 清アルブミン值を当院入院時から経時的に調查し，連携病院退院時の functional independence measure（FIM）を患者転帰の指標として，両者の関連性を調べた。結果：病型は脳梗塞 170 名, 脳出血 105 名, くも膜下出血 20 名であった。 入院中に血清アルブミン值は全病型で低下 し, 最低アルブミン值は脳梗塞で $3.1 \pm 0.6 \mathrm{~g} / \mathrm{dl}$, 脳出血で $3.1 \pm 0.6 \mathrm{~g} / \mathrm{dl}$ と同程度であった。く も膜下出血は $2.6 \pm 0.4 \mathrm{~g} / \mathrm{dl}$ まで大きく低下したが，その後の回復は他の病型と同様であった. 脳梗塞と脳出血においては最低アルブミン值と退院時 FIM 間に正相関がみられたが $(p<$ 0.001), くも膜下出血では関連性は認められなかった．結論：脳卒中リ八患者の血清アルブミ ン値と転帰は病型によって異なり，病型別解析の必要がある。
}

2015 年 2 月 23 日受付, 2015 年 6 月 14 日受理

*1 香川県立中央病院リハビリテーション科/テ 760-8557 香川県高松市朝日町 1-2-1

Department of Rehabilitation Medicine, Kagawa Prefectural Central Hospital

*2 京都滳大学健康科学部理学療法学科/ $\bar{T}$ 607-8175 京都府京都市山科区大宅山田町 34

Department of Physical Therapy, Faculty of Health Science, Kyoto Tachibana University

E-mail : y-ono@chp-kagawa.jp 
Key words : 脳卒中病型 (types of apoplexy), リハビリテーション (rehabilitation), 血清ア ルブミン值（serum albumin），転帰（prognosis）

\section{はじめに}

脳卒中患者に対して急性期病院でのリハビリテー ション（以下，リハ）を含めた治療を行い，その後の 継続した治療及び介護を行っていく上で，初期段階で ある程度の転帰を予測したい. 2008 年度より脳卒中 地域連携クリニカルパス（以下，連携パス）システム に対する診療報酬算定が開始され，香川県高松・東讃 地区でも同年より連携パスに則って，シームレスな医 療を行ってきた. 当院が計画管理病院となって治療し た脳卒中リハ患者について連携病院退院時の状態を記 載した返信を解析することで，ある程度の長期経過の 評価が可能である。その脳卒中患者の転帰関連因子を 解析した結果，血清アルブミン值（以下，アルブミン 值）も重要な因子の 1 つであることが分かった ${ }^{1)}$ 。一 般的な栄養スクリーニング方法には摂取カロリー ${ }^{2 \sim 4)}$, 体重 ${ }^{5)}$ アアルブミン ${ }^{3,6)}$ やプレアルブミン ${ }^{7)}$ などの血 清マーカー，また非常に信頼性の高い栄養評価法とし $\checkmark$ Mini-Nutrition Assessment (MNA) Short Form ${ }^{8)}$ や Subjective Global Assessment (SGA) ${ }^{9)}$ などがあ り，これらの栄養評価と脳卒中患者の長期転帰には正
相関が認められることは従来から報告されている ${ }^{2 \sim 9)}$. 脳卒中病型の中でも脳梗塞に関しては同様な関連が示 されているが3,6)，他の病型の脳卒中での関連性は明 らかになっていない.

血清アルブミンは肝臓でアミノ酸から合成される分 子量 66,000, 半減期 14 〜 18 日の血清蛋白中の 60 $70 \%$ 占める主要なものであるが，炎症，腎蔵およ び肝蔵疾患の影響を受けるため正確な栄養評価方法と はいいがたい.しかし一般病院での栄養スクリーニン グに用いやすく，継時的な変化を適時評価できるた め，アルブミン值と脳卒中患者転帰の関係を調べ，両 者間に関連性があることを説いている報告もある ${ }^{6,10)}$. 本研究では，第一に入院時から長期的にアルブミン值 を随時測定し，脳卒中患者におけるアルブミン值の継 時的変化を病型別に検討し，第二にアルブミン值が病 型別に脳卒中患者転帰に関連があるかどうかを後方視 的に検討した。

\section{対象と方法}

2008 年 8 月から 2014 年 10 月の間で，当院で脳卒 中の急性期治療を行った患者 2103 名（図 1）のうち,

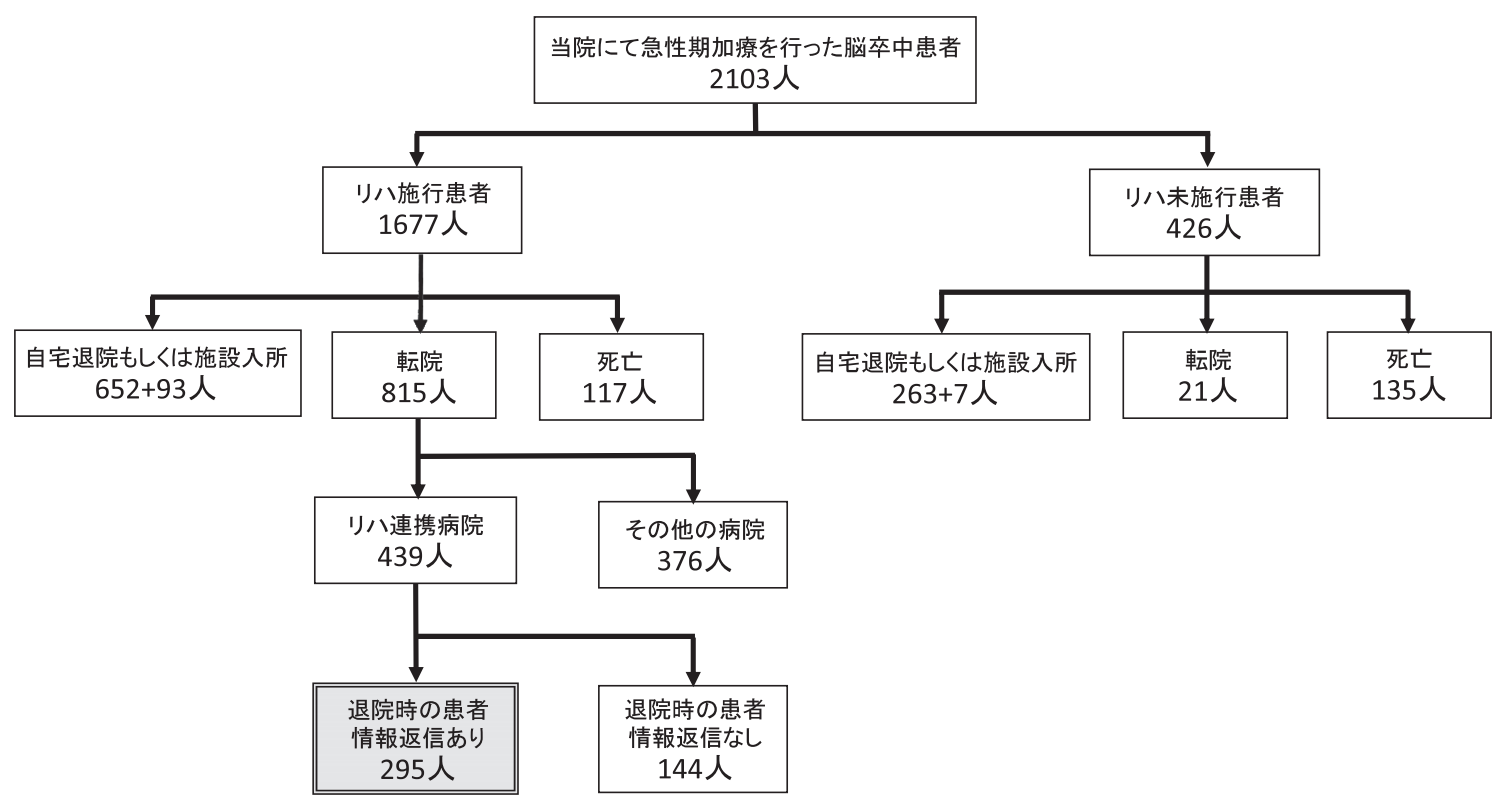

図 1 当院にて急性期加療を行った脳卒中患者の内訳 
小野恭裕・他

表 各測定指標と転帰（退院時 FIM）における相関係数および重回帰分析の結果

\begin{tabular}{|c|c|c|c|c|}
\hline 独立変数 & 測定データ & $\begin{array}{l}\text { 退院時 FIM との } \\
\text { 相関係数 }(r)\end{array}$ & $\begin{array}{c}\text { 退院時 FIM に対する } \\
\text { 標準化係数 } \beta\end{array}$ & $\begin{array}{l}\text { 自由度調整済み } \\
\text { 決定係数 }\end{array}$ \\
\hline 年齢（歳） & $70.3 \pm 13.3$ & $-0.322^{* *}$ & $-0.126^{* *}$ & 0.795 \\
\hline 性別（人） & 男 : 172 女: 123 & -0.082 & 0.009 & \\
\hline 疾患重症度：入院時 NIHSS & $11.0 \pm 7.5$ & $-0.655^{* *}$ & 0.005 & \\
\hline 障害重症度：初回 mRS & $3.06 \pm 1.30$ & $-0.865^{* *}$ & $-0.755^{* *}$ & \\
\hline 炎症所見：最高 CRP 值（mg/dl） & $5.35 \pm 6.12$ & $-0.482^{* *}$ & -0.048 & \\
\hline 最低アルブミン值（g/dl） & $3.13 \pm 0.63$ & $0.616^{* *}$ & $0.129^{* *}$ & \\
\hline 全入院日数（日） & $131.6 \pm 64.8$ & $-0.302^{* *}$ & -0.018 & \\
\hline \multicolumn{5}{|l|}{ 従属変数 } \\
\hline 退院時 FIM & $88.5 \pm 31.1$ & & & \\
\hline
\end{tabular}

リハを行った患者は 1677 名であった。当院から次の 病院に転院になったのは 815 名で，そのうち回復期り 八病院などのリ八連携病院に転院しリハを継続した 患者は 439 名であった。その中で十分なリハが施行さ れ，連携病院退院時の詳細な患者情報の返信が得られ た 295 名を対象とした。

アルブミン值は BCG 法で測定し（正常值 $3.8 \sim 5.3 \mathrm{~g}$ / $\mathrm{dl})$, 当院入院時から退院までの間, 経時的に評価し, 連携病院退院時のアルブミン值についても可能な範囲 で情報収集を行い，当院入院中は複数回測定されてい るので, 本研究ではその最低值を採用し, 経時的変化 を解析した。そしてリ八連携病院でのリハを終了し， 退院する際の Functional Independence Measure（以 下，退院時 FIM）を，リ八を含む治療の転帰の指標 として，アルブミン值との関連性を検討した。統計解 析には SPSS for Windows ver.19を使用し，単変量解 析は Shapiro-Wilk 検定により正規性を検証した上で, Spearmanの順位相関係数を用いて相関関係を解析し た。さらに転帰（退院時 FIM）を従属変数, 患者属 性（年齢，性別）および交絡因子を含む測定指標（疾 患重症度（入院時 NIH Stroke Scale（NIHSS），障害 重症度（初回 modified Rankin Scale (mRS) ), 炎症所 見（最高 C-reactive protein (CRP) 值，最低アルブミ ン值，全入院日数）を独立変数として強制投入による 重回帰分析を行った。

尚，本研究は Helsinki 人権宣言に基づき，当院倫 理委員会倫理問題審査の結果，承認を得て実施した (承認番号 00340).

\section{結 果}

対象は男性 172 名，女性 123 名で，年齢は $22 \sim 99$ 歳（70.3 13.3 歳）であった。病型は脳梗塞 170 名 (57.6\%，平均年齢 74.7 歳)，脳出血 105 名（35.6\%， 平均年齢 65.5 歳), 〈も膜下出血 20 名 $(6.8 \%$, 平均 年齢 58.3 歳) であった。

全対象者における転帰（退院時 FIM）を従属变数 とした重回帰分析の結果，年齢，障害重症度（初回 $\mathrm{mRS})$, 最低アルブミン值の 3 因子が抽出された (表).

さらに最低アルブミン值に着目したところ，全病型 の平均值（土標準偏差）（図 2）は発症直後の入院時 が $4.0 \pm 0.5 \mathrm{~g} / \mathrm{dl}$ と最も高く, 入院後 $3.1 \pm 0.6 \mathrm{~g} / \mathrm{dl}$ ま で一旦低下するが，転院前には $3.4 \pm 0.6 \mathrm{~g} / \mathrm{dl}$ と回復 し，連携病院退院時にはほぼ発症時の值 $(3.8 \pm 0.4 \mathrm{~g} /$ dl）までに回復していた。次に病型別に脳梗塞，脳出 血およびくも膜下出血と分けて検討を行った。当院入 院時のアルブミン值はいずれの病型でも $4.0 \mathrm{~g} / \mathrm{dl}$ 前後 であり，ほぼ同じ值であった。入院中のアルブミン值 の最低值は脳梗塞で $3.1 \pm 0.6 \mathrm{~g} / \mathrm{dl}$, 脳出血で $3.1 \pm$ $0.6 \mathrm{~g} / \mathrm{dl}$ と同程度であったが, くも膜下出血は $2.6 \pm$ $0.4 \mathrm{~g} / \mathrm{dl}$ まで大きく低下していた。しかし, 当院退院 時には全ての病型で $3.4 \pm 0.6 \mathrm{~g} / \mathrm{dl}$ まで回復し, 連携 病院退院時には全ての病型でさらに回復し，ほほ同じ 值であった。

さらに病型別におけるアルブミン值と転帰（連携病 院退院時 FIM）の関係を検討した（図 3)。全病型を 

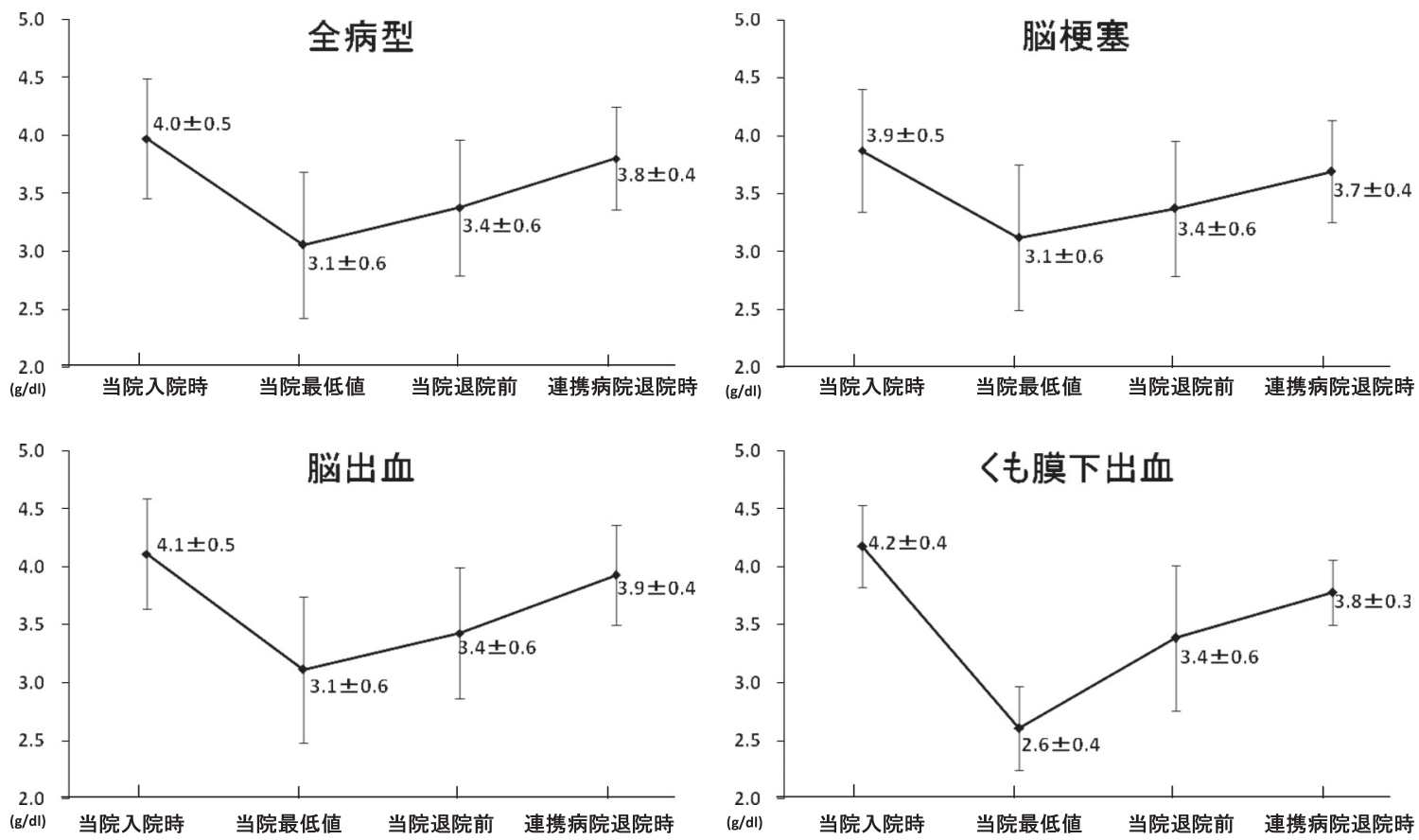

図 2 当院入院時から連携病院退院時までの経時的な血清アルブミン值の推移

入院中のアルブミン值の一過性低下は脳梗塞と脳出血では同程度であったが，くも膜下出血ではより大きな低下であった (表示は平均值 \pm 標準偏差, 単位は $\mathrm{g} / \mathrm{dl}$ ).
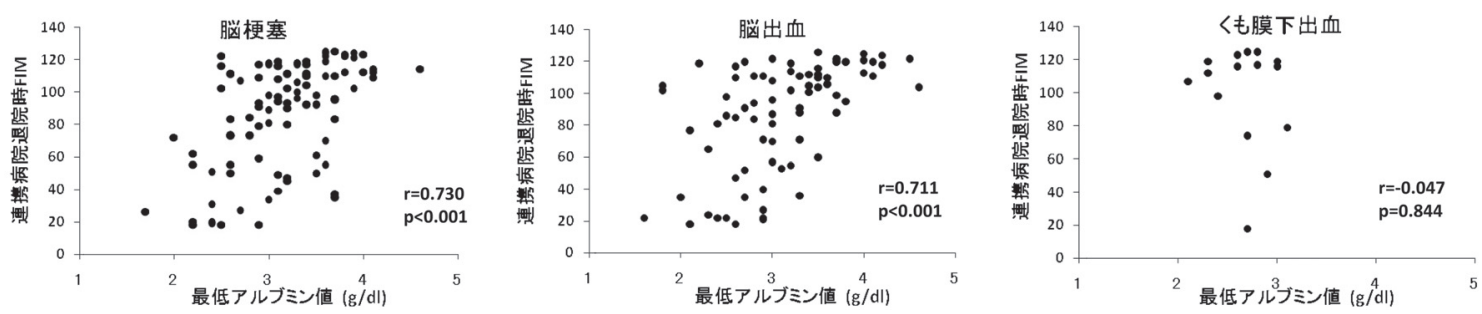

図 3 病型別の最低アルブミン值と転帰（連携病院退院時 FIM）の関係 病型別には脳梗塞と脳出血においては最低アルブミン值と連携病院退院時 FIM 間に正相関がみられたが $(p<0.001)$, くも 膜下出血においては関連は認められなかった $(p=0.844) . r$ : Spearman の順位相関係数.

含めた検討では最低アルブミン值が低いと退院時

FIM が低く，最低アルブミン值が高いと退院時 FIM が高いといった正の相関を認め $(p<0.001)$, アルブ ミン值と転帰との関連性が示唆された。しかし病型別 にみると, 脳梗塞と脳出血においては最低アルブミン 值と退院時 FIM 間に正相関がみられた（いずれも $p<0.001)$ が，くも膜下出血では全く関連性が認めら れず $(p=0.844)$, 病型によりアルブミン值の転帰へ の関与が異なることが示された。

\section{考察}

急性期脳卒中患者に対して早期リハや積極的なリハ 介入の重要性が言われている ${ }^{11,12)}$ 。当院でも基本的に その方針でリハを行っているが，低アルブミン状態 で，蛋白合成が十分にできない患者に対し，積極的に リハを強いるのは返って異化立進, 体力および免疫力 低下を助長する懸念がある. 本研究の第一の課題であ るアルブミン值の経時的変化の検討から，ほとんどの 急性期脳卒中患者において一旦はアルブミン值が低下 
し, その後回復過程をとること, 病型別には, くも膜 下出血は他の病型に比べて, 一過性にはアルブミン值 の低下がより深刻であることが示された。脳卒中患者 は入院後，意識状態の変動，嚥下障害，手術や抗血栓 療法などの治療のため，絶食を強いられることも多 く，一定の安定した食事もしくは経管栄養がなされる までは，アルブミン值はマイナスバランスと考えられ る.くも膜下出血は脳卒中の中でも劇症型出血であ り，開頭手術やカテーテル治療など高侵襲治療の影 響，脳血管攣縮や水頭症などの合併により異化光進が 大きい。従って，刻々と変化する病態に対して主治医 と十分検討し，適宜リハメニューを考慮していく必要 があると思われる。

第二に本研究ではアルブミン值が脳卒中患者転帰に 関連があるかどうかを検討した。単変量解析では全病 型，また病型別に脳梗塞と脳出血においては最低アル ブミン值と退院時 FIM の関係がみられ，先行研究に 矛盾しない結果であった ${ }^{6,10)}$. 重回帰分析でも最低ア ルブミン值は退院時 FIM の独立した関連因子であっ た。その他に病型や障害重症度（初回 $\mathrm{mRS）が}$ 転帰 関連因子であった。しかし, 病型別と最低アルブミン 值の関係から，〈も膜下出血は他の病型とは異なり， 最低アルブミン值の転帰への関与は認めなかった。前 述のようにくも膜下出血はアルブミン值以外の合併し てくる複合病態の影響が大きいと思われ，逆にアルブ ミン值が低くても, 複合合併症を乗り切り, 十分な回 復期リハができれば，比較的良好な転帰が得られる可 能性を示唆していると思われた。

本研究の限界として(1)ハ連携病院からの退院時情 報のあった限られた患者のみを対象としていること， (2)食事が経口か経管栄養か，嚥下機能評価が不十分で あること，(3)調べたのはアルブミン值のみであり，厳 密な栄養状態の把握ではないこと, (4)心大血管, 呼吸 器, 消化器および運動器疾患などの合併症やその治療 内容についての把握ができていないことなどが挙げら れ，今後さらに解析していかなければならないと思わ れる。

\section{文献}

1）小野恭裕, 本田 透, 桑嶋博史, 菰㴊真紀, 塩田和輝 : 脳 卒中地域連携クリニカルパスにて加療した脳卒中患者 の転帰関連因子. J Clin Rehabil 2014 ; $23: 1020-1023$

2) Kitsosg, Harris D, Pollack M, Hubbard IJ : Assessments in Australian stroke rehabilitation units : a systematic review of the post-stroke validity of the most frequently used. Disabil Rehabil $2011 ; 33: 2620-2632$

3) Aquilani R, Sessarego P, Ladorola P, Barbieri A, Boschi F : Nutrition for brain recovery after ischemic stroke : an added value to rehabilitation. Nutr Clin Pract $2011 ; 26$ : 339-345

4) Chang EY, Chang EH, Cragg S, Cramer SC : Predictors ofgains during inpatient rehabilitation in patients with stroke-A review. Crit Rev Phys Rehabil Med 2013 ; 25 : 203-221

5) Paquereau J, Allart E, Romon M, Rousseaux M : The long-term nutrition status in stroke patients and its predictive factors. J Stroke Cerebrovasc Dis 2014 ; 23 : 1628-1633

6) Cho YM, Choi IS, Bian RX, Kim JH, Han JY, Lee SG : Serum albumin at admission for prediction of functional outcome in ischaemic stroke patients. Neurol Sci 2008 ; 29 : 445-449

7) Pellicane AJ, Millis SR, Barker KD, Temme KE, Sayyad A, Oswald MC, Roth EJ : The effect of protein and calorie intake on prealbumin, complications, length of stay, and function in the acute rehabilitation inpatient with stroke. NeuroRahabilitation $2013 ; 33: 367-376$

8) Nip WF, Perry L, McLaren S, Mackenzie A : Dietary intake, nutritional status and rehabilitation outcomes of stroke patients in hospital. J Hum Nutr Diet 2011 ; 24 : 460-469

9) Pandian JD, Jyotsna R, Singh R, Sylaja PN, Vijaya P, Padma MV, Venkateswaralu K, Sukumaran S, Radhakrishnan K, Sarma PS, Mahew R, Singh Y : Premorbid nutrition and short term outcome of stroke : a multicentre study form India. J Neurol Neurosurg Psychiatry 2011 ; $82: 1087-1092$

10) Babu MS, Kaul S, Dadheech S, Rajeshwar K, Jyothy A, Munshi A : Serum albumin levels in ischemic stroke and its subtypes : correlation with clinical outcome. Nutrition $2013 ; 29: 872-875$

11）出口貴行, 藤本俊一郎, 大平隆博, 平尾寛子, 塩田和代： 脳卒中地域連携クリティカルパスからみた在宅復帰に 影響する関連因子の検討. 日本医療マネジメント学会 杂倠誌 $2012 ; 12: 216-220$

12）斎藤 潤, 永田智子, 木佐俊郎, 酒井康生, 小野惠司, 三 谷敏史 : 急性期病院と回復期リハビリテーション病棟 間の脳卒中地域連携パスと転帰に影響する因子の検討. Jpn J Rehabil Med 2010 ; 47 : 479-484 